\title{
Membangun Reformasi Birokrasi Berkinerja Dalam Mewujudkan Good Governance di Kabupaten Gorontalo
}

\author{
Suaib Napir \\ Program Studi Ilmu Pemerintahan, Universitas Gorontalo \\ Jalan A. A. Wahab No. 247, Limboto
}

\begin{abstract}
This study aims to analyze, identify and describe strengthening Local Government Organisation Gorontalo District; Methods: Using qualitative research, data collection techniques; observation, interviews and documents. data analysis interactive model of Miles, Hubermen and Saldana (2014). The results showed that: Strengthening the organization, which includes; 1) the incentive has been running with a performance-based; 2) utilization of personnel not comply pd principle the right man on the right pleace; 3) leadership is more motivation in improving individual and organizational performance; 4) organizational culture refers to the Standard Operating Procedure (SOP) that have been standard; 5) communication has been running well, but need to increase understanding of the message to avoid mis communication between SKPD; 6) organizational structure has been carried out by the organization's needs but still dependent on central government policy to discretionary policies at local level walk less than the maximum.
\end{abstract}

Key words: Organizational Strengthening, Institutional Reform, Good Governance

\begin{abstract}
ABSTRAK
Penelitian ini bertujuan menganalisis, mengidentifikasi dan mendeskripsikan bagaimana penguatan organisasi Pemerintah Daerah dalam mewudjukan good governace di Kabupaten Gorontalo. Metode Penelitian: Menggunakan jenis penelitian kualitatif, teknik pengumpulan data; observasi, wawancara dan dokumen. teknik analisis data model interaktif Miles, Hubermen dan Saldana (2014). Hasil penelitian menunjukkan bahwa: Penguatan organisasi, yang meliputi; 1) pemberian insentif telah berjalan dengan berbasis kinerja; 2) pemanfaatan personil belum mengacu pd asas the right man on the right pleace; 3) leadership lebih bersifat motivasi dalam menigkatkan kinerja individu dan organisasi; 4) kultur organisasi mengacu pada Standar Operasional Prosedur (SOP) yang telah baku; 5) komunikasi telah berjalan baik namun perlu peningkatan pemahaman pesan untuk menghindari mis komunikasi antar SKPD; 6) struktur organisasi telah dilakukan berdasarkan kebutuhan organisasi namun masih dipengaruhi dengan kebijakan pemerintah pusat hingga diskresi kebijakan pada level daerah berjalan kurang maksimal.
\end{abstract}

Kata Kunci: Penguatan Organisasi, Reformasi Kelembagaan, Good Governance. 


\section{PENDAHULUAN}

Reformasi birokrasi merupakan salah satu agenda dari otonomi daerah. Sebab otonomi daerah memberikan kewenangan kepada daerah untuk mandiri dalam memajukan masyarakatnya secara demokratis, baik di bidang politik, ekonomi, maupun sosial budaya. Reformasi birokrasi sebagai sarana untuk membuat sistem administratif menjadi instrumen yang efektif bagi perubahan sosial, serta instrumen untuk menciptakan persamaan politik, keadilan sosial, dan pertumbuhan ekonomi. Proses reformasi birokrasi dapat dilihat sebagai berubahnya praktik-praktik, tingkah laku, dan struktur birokrasi yang telah mapan. Reformasi birokrasi masih terus bergulir dan belum dapat memenuhi harapan masyarakat. Reformasi birokrasi membutuhkan waktu dan tahapan, karena kompleksitas permasalahan, tingginya tingkat penyalahgunaan wewenang, banyaknya praktik korupsi, kolusi dan nepotisme (KKN), dan lemahnya pengawasan terhadap kinerja aparatur pemerintah.

Reformasi birokrasi merupakan bagian penting dalam mewujudkan good governance (tata kelola pemerintahan yang baik). Titik berat pemerintahan yang baik terletak pada upaya peningkatan kualitas kinerja, serta pemberantasan korupsi secara terarah, sistematis, dan terpadu. Good governance biasanya digunakan sebagai indikator terealisasinnya reformasi birokrasi dengan adanya partisipasi masyarakat, tegaknya supremasi hukum, transparansi, kepedulian kepada stakeholders, berorientasi pada konsensus, kesetaraan, efektivitas dan efisiensi, akuntabilitas, dan visi strategis.

Reformasi birokrasi di Kabupaten Gorontalo bertujuan untuk menciptakan birokrasi berkinerja tinggi. Dengan mengacu pada Peraturan Menteri PAN RB tentang Road Map Reformasi Birokrasi, pemerintahan berbasis kinerja ditandai dengan beberapa hal, yaitu: 1) Penyelenggaraan pemerintahan dilaksanakan dengan berorientasi pada prinsip efektif, efisien, dan ekonomis; 2) Kinerja pemerintah difokuskan pada upaya untuk mewujudkan outcomes (hasil); 3) Seluruh instansi pemerintah menerapkan manajemen kinerja yang didukung dengan penerapan sistem berbasis elektronik untuk memudahkan pengelolaan data kinerja; 4) Setiap individu pegawai memiliki kontribusi yang jelas terhadap kinerja unit kerja terkecil, satuan unit kerja di atasnya, hingga pada organisasi secara keseluruhan.

Indikator Pemerintahan berbasis Kinerja sebagaimana disebutkan diatas belum terdapat dalam penyelenggaraan pemerintahan di Kabupaten Gorontalo. Dapat dilihat pada realisasi rasio alokasi belanja langsung dan belanja tak langsung sebesar $39 \%$ : 61 \% (RPJMD : 2016-2021) dalam kurun waktu tiga tahun terakhir sampai dengan tahun 2016. Rasio ini belum mencapai angka ideal dan juga belum efisien. Penyelenggaran pemerintahan daerahpun belum berorientasi pada good private governance. Hal ini dapat ditunjukan oleh indicator ekonomi makro Incremental Capital Output Ratio (ICOR) Kabupaten Gorontalo dengan rata-rata selama lima tahun berada di atas angka 5 (ICOR Kabupaten Gorontalo 2016). Dimana investasi pemerintah Kabupaten yang ditanamkan selama lima tahun pada lag 0 belum menghasilkan output. Artinya produktivitas investasi pemerintah selama lima tahun terakhir masih dinilai rendah pada pemerintah daerah Kabupaten Gorontalo.

Efektivitas penyelengaraan pemerintahan pada sector kesejahteraan rakyat juga selama 5 tahun terakhir belum menunjukan keefektifan. Hal itu dapat dinilai dengan koefisien gini ratio sampai pada tahun 2015 sebesar 0.41 , 
nilai ini berada pada kategori ketimpangan sedang. Sementara itu, presentase penduduk miskin berdasarkan data BPS tahun 2016 berada di angka $21.80 \%$. Angka ini berada pada level angka tertinggi kedua diantara Kabupaten Kota di Propinsi Gorontalo. Masalah tersebut menunjukkah bahwa efektivitas penyelenggaraan pemerintahan masih rendah, dimana pemerintaha daerah belum mampu memperkecil disparitas pendapatan sebagaimana ditunjukan oleh indeks gini dan Prosentase penduduk miskin sebagai ukuran kesejahteraan. Menurut Simanjuntak bahwa Penentuan dimensi kinerja dalam reformasi birokrasi tersebut dilakukan dengan pertimbangan bahwa teori kinerja tersebut memiliki dimensi yang dapat mendukung untuk pencapaian kinerja pegawai dalam organisasi yang dilakukan dengan kompetensi individu, dukungan organisasi, dan dukungan manajemen.

Indikator utama pemerintahan berbasis kinerja ditunjukan dengan Kinerja pemerintah yang fokus pada upaya untuk mewujudkan outcomes. Dalam konteks Kabupaten Gorontalo, aspek ini termasuk kategori belum tercapai. Indikator yang dapat digunakan ukuran pemerintahan berbasis outcome nampak pada hasil penilaian Laporan Akuntabilitas Kinerja Instansi Pemerintah Kabupaten Gorontalo yang sampai tahun 2015 masih pada level nilai CC (cukup baik). Artinya secara substansi kinerja pemerintah daerah belum focus pada outcome base. Berdasarkan fakta-fakta tersebut maka Reformasi Birokrasi adalah sebuah keharusan bagi Pemerintah Kabupaten Gorontalo dalam meningkatkan kinerja birokrasi pemerintahan daerah.

\section{METODE PENELITIAN Jenis Penelitian}

Jenis penelitian ini adalah penelitian deskriptif dengan menggunakan pendekatan kualitatif. Penelitian ini menggunakan analisis institusionalisme karena penelitian ini dilakukan pada suatu bagian organisasi pemerintahan daerah. Pierson \& Skocpol (2008), menyatakan bahwa analisis institusional digunakan untuk mengkaji segala sesuatu tentang membangun reformasi birokrasi berknerja dalam mewujudkan good governance di Kabupaten Gorontalo

\section{Lokasi Penelitian}

Penelitian dilaksanakan pada pemerintah daerah di Kabupaten Gorontalo dengan lokasi penelitian diambil, yakni: Badan Kepegawaian Daerah, Pendidikan dan Pelatihan, Dinas Pendidikan Dan Kebudayaan, Dinas Kesehatan Dan Dinas Koperasi UMKM Perindustrian Dan Perdagangan telah merepresentasikan Satuan Kerja Perangkat Daerah (SKPD) yang dapat mewujudkan visi Pemerintah Daerah Kabupaten Gorontalo sebagai "kabupaten yang sehat, cerdes dan kreatif. Lokasi penelitian aksesibilitasnya cukup memadai baik akses untuk memdapatkan data sukunder dan primer juga jarak keterjangkauan sehingga memudahkan dapat menghemat biaya, tenaga dan waktu

\section{Pengumpulan Data}

Teknik pengumpulan data yang digunakan dalam penelitian yaitu dengan menggunakan observasi, wawancara, dan dokumentasi. Wawancara mendalam (Indepth Interview), yaitu teknik pengumpulan data dimana peneliti secara langsung mengadakan tanya jawab dengan informan yang dipilih dalam penelitian. Dokumentasi, yaitu teknik pengumpulan data yang dilakukan untuk mendokumentasikan semua data dan informasi yang diperoleh dari Pemerintah 
daerah Kabupaten Gorontalo. Penemuan sumber data pada orang yang diwawancarai dilakukan secara purposive sampling, yaitu dipilih dengan pertimbangan dan tujuan tertentu. Informan penelitian ini adalah Bupati, Setda, Badan Kepegawaian Daerah, Pendidikan dan Pelatihan, Dinas Pendidikan Dan Kebudayaan, Dinas Kesehatan Dan Dinas Koperasi UMKM Perindustrian Dan Perdagangan.

\section{Analisis Data}

Menurut Norman (2009), kegiatan analisis data kualitatif mencakup pengujian, mengerutkan, mengkategorikan, mengevaluasi, membandingkan, mensintesiskan dan mengkontemplasikan data yang dikode seperti halnya interview data mentah dan data yang direkam. analisis data yang dilakukan dalam penelitian ini melalui analisis kualitatif dengan tahapan pengelolaan data yaitu penafsiran data, reduksi data, penyusunan data, pemeriksaan keabsahan data, Menarik kesimpulan.

\section{HASIL DAN PEMBAHASAN}

Reformasi birokrasi bukanlah sekedar perubahan struktur dan reposisi birokrasi. Lebih dari itu reformasi birokrasi harus meliputi perubahan system politik dan hokum secara menyeluruh, perubahan sikap mental dan budaa birokrat dan masarakat serta perubahan mindset dan komitmen pemerintah dan partai politik. Harus terdapat kejelasan batas antara pejabar karier dan pejabat politik, baik birokrasi pusat maupun birokrasi daerah. hal ini juga dimaksudkan untuk membatasi pejabat politik dalam birokrasi. Sebagaimana diterapkan di Negara-nagara maju, makapejabat politik hanya dimungkinkan jika dipilih secara langsung oleh rakyat atau mendapatkan pesetujuan dari pejabat yang dipilih oleh rakyat. Profesionalitas dan netralitas birokrasi karena itu harus merupakan sasaran utama reformasi birokrasi. Hal terpenting dalam reformasi birokrasi adalah komitmen dan national leadership. Tanpa komitmen baik dari eksekutif, legislative, dan yudikatif, reformasi birokrasi hanyalah blue print ang berbeda dalam konteks wacana.

Kabupaten Gorontalo merupakan salah satu daerah yang memiliki potensi, namun belum dikelola secara maksimal akibat karena lemahnya kinerja birokrasi pemerintahan daerah. Lemahnya kinerja birokrasi pemerintah daerah akibat pengaruhi proses pelayanan birokrasi terlalu panjang dan kaku. Masyarakat menilai bahwa pelayanan birokrasi masih berbelit-berlit dan itu menyebabkan urusan birokrasi menjadi lamban. Lemahnya kinerja birokrasi merupakan faktor penghambat dan lambat dalam memberikan respon terhadap berbagai potensi dan peluang dalam membangun birokrasi berkinerja tinggi. Banyak peluang tidak dapat dikelola dengan baik oleh birokrasi dalam memajukan pembangunan daerah.

Rendahnya kinerja birokrasi dapat dilihat dalam Laporan Akuntabilitas Kinerja Instansi Pemerintah Kabupaten Gorontalo sampai tahun 2015 masih pada level nilai CC (cukup baik). Indikator Pemerintahan berbasis Kinerja sepenuhnya belum tercermin dalam penyelenggaraan pemerintahan di Kabupaten Gorontalo dalam kurun waktu beberapa tahun ini. Hal ini disebabkan karena Mindset dan cultural aparatur, integritas dan kinerja belum sesuai standar yang sudah diatur. Saat ini, mindset dan culture aparatur masih dalam tataran menunggu arahan, masalah petunjuk dan alasan belum ada 
perintah pimpinan menjadi alasan dan tameng birokrasi dalam bekerja. Apartur lulusan pendidikan tinggi sebanyak 56,34\% dari total PNS yang terdiri dari pendidikan S1 3.242 PNS, S2 345 PNS, S3 7 PNS. Pendidikan aparatur Kabupaten Gorontalo dapat menunang dalam melakukan tugas dengan cepat dan tanggap terdapat tuntutan, kepentingan dan kebutuhan rakyat. Realitas menunjukkan bahwa daya dukung SDM untuk mencapai sasaran organisasi masih belum optimal.

Tugas dan fungsi birokrasi pemerintah daerah di Kabupaten Gorontalo ditemukan bahwa sistemnya masih belum maksimal. Hal ini ditandai dengan adanya dominasi kepemimpinan kepala daerah yang pragmatis. Kinerja organisasi perangkat daerah (OPD) lebih banyak melakukan perjalanan dinas dibandingkan dengan kinerja yang pro pada pembangunan daerah. Banyak kalangan menilai bahwa banyaknya perjalanan dinas yang dilakukan pemerintah daerah Kabupaten Gorontalo dinilai bagian dari bentuk pemborosan anggaran atau hanya menghabiskan belanja negara. Pada sisi yang lain, anggaran pemerintah daerah telah tersedia dengan baik, sasaran jelas, indikator dan pengukurannya juga sudah ada, serta panduan pengukurannya sudah diatur melalui peraturan menteri, namun pemerintah daerah belum optimal dalam mewujudkan birokrasi berkinerja masih rendah.

Indikator birokrasi yang menunjukkan masih memiliki kinerja rendah adalah belum efisien realisasi rasio alokasi belanja langsung dan belanja tak langsung pemerintah daerah kabupaten Gorontalo. Realisasi rasio alokasi belanja langsung dan belanja tak langsung sebesar $39 \%: 61 \%$ (RPJMD : 20162021) dalam kurun waktu 2014 sampai dengan tahun 2016. Rasio ini belum mencapai angka ideal ketika diukur nilai efisiensi. Hal ini menunukkan bahwa substansi kinerja pemerintah daerah belum focus pada outcome base. Karena itu diperlukan model Reformasi Birokrasi dalam meningkatkan kinerja pemerintah daerah dan itu merupakan sebuah keharusan untuk dibangun Pemerintah Kabupaten Gorontalo.

Selain itu, perjalanan dinas ke luar daerah yang berlebihan menyebabkan tidak efektifnya kinerja birokrasi karena waktu pelayanan pemerintah kepada masyarakat semakin berkurang. Perjalanan dinas pemerintah daerah yang berlebihan menyebabkan belanja untuk program kepada masyarakat terabaikan, sehingga pada triwulan pertama (I) terdapat beberapa proyek atau kegaitan tidak terlaksana seuai perencanaan. Oleh karena itu, birokrasi pemerintah daerah di Kabupaten Gorontalo diharapkan dapat lebih memfocuskan anggaran pada program-program pemerintah dengan prinsip tepat waktu dan tepat sasaran sehingga ekonomi pembangunan tidak terjadi ketimpangan.

Koefisien Gini Ratio sampai dengan tahun 2016 sebesar 0.41 berada pada kategori ketimpangan sedang. Sedangkan prosentase penduduk miskin berdasarkan data BPS tahun 2016 masih berada di angka 21.80\%. Angka ini berada pada level angka tertinggi kedua diantara Kabupaten dan Kota di Propinsi Gorontalo. Hal ini disebabkan karena lambatnya investasi pemerintah, hal itu berpengaruh pada lambatnya stimulus ekonomi. Lambat pertumbuhan ekonomi pembangunan menyebabkan pertumbuhan ekonomi pembangunan suatu daerah menjadi lambat.

Kondisi pemerintah daerah dikabupaten Gorontalo ditemukan sejumlah fakta tentang masalah sumberdaya aparatur ini dalam 5 tahun terakhir 
menunjukan anggaran gaji pegawai meningkat rata-rata setiap tahun, namun kinerja masih lemah. Pada tahun 2016 belanja pegawai sebesa 66 persen, sementara belanja pembangunan relative kecil. Oleh karena itu pemerintah daerah dituntut lebih optimal membangun birokrasi berkinerja dalam meningkatkan pembangunan daerah. Selain itu, pemerintah daerah Kabupaten Gorontalo dapat lebih eksis dalam mewujudkan tata kelola pemerintahan yang baik (good governance).

Sebagai dasar dalam sistem pemerintahan, daerah mempunyai aparatur yang menjalankan roda pemerintahan. Namun birokrasi tidak bisa hanya dilihat dari segi aparatur yang menjadi abdi negara, melainkan harus dilihat secara keseluruhan sebagai sebuah sistem yang sangat kompleks sebagai pendorong jalannya roda pemerintahan. Birokrasi di Indonesia kini dipaksa untuk digeser agar berjalan sesuai dengan pakemnya. Pemerintah pun bergerak untuk merumuskan sebuah peraturan untuk menjadi landasan pelaksanaan reformasi birokrasi dengan mengeluarkan Peraturan Presiden No. 80 Tahun 2011 tentang Grand Design Reformasi Birokrasi Indonesia 2010-2025. Birokrat harus mengubah pola kerja yang pada awalnya birokrasi berdasarkan peraturan (rule based bureaucracy) menuju performance based bureaucracy yang pada akhirnya akan mengerucut menjadi dynamics government. Hal ini dilakukan untuk mewujudkan good and clean government yang ditetapkan melalui percepatan implementasi reformasi birokrasi. Dengan demikian, pemerintah melakukan penataan kembali terhadap sistem penyelenggaraan pemerintah, di mana birokrasi akan menjadi tulang punggung perubahan.

Pemerintah Pusat menyadari bahwa reformasi birokrasi di Indonesia berjalan sangat lambat akibat pola pikir dan perilaku birokrat yang belum berkomitmen untuk berubah. Oleh karenanya, Presiden Joko Widodo kemudian mengeluarkan semangat perubahan melalui "Revolusi Mental".Revolusi mental memang dirasa perlu dilakukan untuk mengubah mindset dan culture set aparatur yang selama ini seolah berperilaku layaknya priyayi. Revolusi mental menekankan tiga aspek penting yang harus ditanamkan, yaitu integritas, etos kerja, dan gotong royong. Ketiga hal tersebut yang kemudian harus diaplikasikan oleh birokrat dalam rangka percepatan reformasi birokrasi. Pelaksanaan reformasi birokrasi dapat dilihat dari tiga indikator utama yaitu Indeks Persepsi Korupsi, Peringkat Kemudahan Berusaha (ease of doing business/eodb) dan jumlah instansi pemerintah yang memiliki akuntabilitas tinggi.

Berdasarkan survey Lembaga Tranparency International (TI), indeks persepsi korupsi di Indonesia tahun 2016 mengalami perbaikan. Indonesia menempati posisi 88 dari 168 negara, di mana pada tahun sebelumnya, indeks persepsi korupsi Indonesia berada pada peringkat 107. Untuk peringkat kemudahan berusaha, Bank Dunia juga telah merilis bahwa Indonesia mengalami perbaikan posisi jika dibandingkan periode sebelumnya, di mana tahun 2016 Indonesia menempati urutan 109 dari sebelumnya peringkat 120. Begitu pula dengan akuntabilitas instansi pemerintah juga terus mengalami perbaikan. Hal tersebut tercermin dari banyaknya komitmen yang muncul diberikan pimpinan instansi, baik pusat maupun daerah. Dengan banyaknya komitmen tersebut, mengindikasikan besarnya kepedulian pimpinan setiap instansi pemerintah untuk melakukan perubahan dalam rangka memperbaiki tata kelola pemerintahan. 
Pada prinsipnya, tujuan akhir membangun Birokrasi berkinerja di Kabupaten Gorontalo adalah untuk menciptakan birokrasi yang berkinerja tinggi dan menjadi pra kondisi untuk menuju Birokrasi yang Dinamis. Tujuan akhir ini merupakan penyelarasan dengan tujuan jangka panjang Reformasi Birokrasi di Indonesia. Dengan mengacu pada Peraturan Menteri PAN RB tentang Road Map Reformasi Birokrasi, Pemerintahan berbasis kinerja ditandai dengan beberapa hal, antara lain: (1) Penyelenggaraan pemerintahan dilaksanakan dengan berorientasi pada prinsip efektif, efisien, dan ekonomis; (2) Kinerja pemerintah difokuskan pada upaya untuk mewujudkan outcomes (hasil); (3) Seluruh instansi pemerintah menerapkan manajemen kinerja yang didukung dengan penerapan sistem berbasis elektronik untuk memudahkan pengelolaan data kinerja; (4) Setiap individu pegawai memiliki kontribusi yang jelas terhadap kinerja unit kerja terkecil, satuan unit kerja di atasnya, hingga pada organisasi secara keseluruhan. Setiap instansi pemerintah, sesuai dengan tugas dan fungsinya, secara terukur juga memiliki kontribusi terhadap kinerja pemerintah secara keseluruhan.

\section{PENUTUP}

Penelitian ini menunjukkan bahwa penguatan organisasi Pemerintah Daerah dalam mewudjukan good governace di Kabupaten Gorontalo meliputi; pertama, pemberian insentif telah berjalan dengan prinsip insentif berbasis kinerja; kedua, pemanfaatan personil belum mengacu pd asas the right man on the right pleace; ketiga, leadership lebih bersifat motivasi dalam menigkatkan kinerja individu dan organisasi; keempat, kultur organisasi mengacu pada Standar Operasional Prosedur (SOP) yang telah baku; kelima, komunikasi telah berjalan baik namun perlu peningkatan pemahaman pesan untuk menghindari mis komunikasi antar SKPD; keenam, struktur organisasi telah dilakukan berdasarkan kebutuhan organisasi namun masih dipengaruhi dengan kebijakan pemerintah pusat hingga diskresi kebijakan pada level daerah berjalan kurang maksimal. Penulis menyarankan agar penguatan organisasi dapat dilakukan pemberian insentif ditingkatkan dan menjaga sustainabilitasnya, pemanfaatan personil disesuaikan keahlian dan kebutuhan masing-masing SKPD, leadership menjadi best practice dalam pengelolaan organisasi, kultur organisasi menjadi acuan dalam meningkatkan kinerja individu dan kinerja organisasi, komunikasi menjadi sarana untuk meningkatkan koordinasi antar SKPD, dan struktur manajerial dilakukan berdasarkan kebutuhan organisasi yang berbasis marit system.

\section{REFERENSI}

Bhatta, G. 1996. Capacity Building at the Local Level for Effective Governance, Empowerment Without Capacity is Menagingless. International Conference on Governance Innovations. Manila. Philippines

Keban, Y.T. 2000. Artikel "Good Governance dan Capacity Building sebagai Indikator Utama dab Fokus Penilalain Kinerja Pemerintah. Jurnal Perencanaan Pembangunan, Jakarta

Lembaga Administrasi Negara 2012. Capacity Building, Birokrasi Pemerintah Daerah. Makassar: STIA LAN

Lembaga Administrasi Negara. 2000. Pedoman Pelaporan Kinerja Instansi Pemerintah, LAN-RI.Jakarta. 
LAN, 2004; Teknik Penyusunan Organisasi Berkinerja Tinggi, Jakarta, Pusat kajian Kinerja Kelembagaan LAN.

Lubis, Hari \& Huseini, Martani, (1987). Teori Organisasi; Suatu Pendekatan Makro. Pusat Antar Ilmu-ilmu Sosial UI: Jakarta

Moekijat, (1990). Pengembangan Organisasi. Remaja Karya: Bandung.

Norman Denzin. K. (2009). Qualitatid Reseach. Yogyakarta: Pustaka Pelajar.

Sedarmayanti 2007. Sumber Daya Manusia dan Produktivitas Kerja. Cetakan Kedua. Bandung. Mandar Maju.

Siagian, P. Sondang. 1998, Organisasi Kepemimpinan dan Prilaku Organisasi, Bumi Aksara, Jakarta.

Soekanto. 2002. Efektivitas Kinerja; Tinjauan Kritis Organisasi. Rineka Cipta. Jakarta.

Sutarto, (1985). Dasar-dasar Organisasi. Gadjah Mada University: Yogyakarta.

Pierson \& Skocpol. (2008). Historical institusinalism in Contemporary Political Science. Dalam I. Katzenold \& H.V. Miller (ed). New York: W. W. Norton.

UNDP, 1997. Governance for Sustainable Development-A Policy Documen, New York: UNDP 1998. Capacity Assessment and Development in a Systems and Strategic Management Context. Technical Advisory Paper No.3. Management Development and Governance Division, Bureau for Development Policy. New York. , 2006. Indeks Pembangunan Manusia. Jakarta. UNDP 